Ю.О.Омельченко, аспірант Інституту філософії імені Г.С. Сковороди НАН України

\title{
КОНЦЕПТОСФЕРА «ІНТЕРНЕТ «РОЗУМНИХ» РЕЧЕЙ» ТА ЇЇ ФІЛОСОФСЬКИЙ СМИСЛ
}

Продукти сучасної науки, NBICS-інженерія, Big data та Mega science, Hi-tech та Hi-hume технології, захоплюють все ширші топоси людського буття. Поступ технонауки призводить до глобалізації й інтеграції світу, робить техніку доступною та незамінною. Сьогодні стало складно уявити медицину, побут, державу, політику, право, сільське господарство, економіку, освіту, культуру, науку, мистецтво без сучасної інженерії. Вінцем розробок останньої стає унікальна соціотехнічна система Інтернет «розумних» речей (IPP), яка об’єднує всіх людей та «розумні» речі у єдиний простір.

Техноеволюція XXI ст. справляє всеохоплений вплив на людину і $є$ однією з найважливіших ланок поступу людства. Техніка, як зовнішній неорганічний орган людини та продовження біологічних сенсорів і актуаторів, стала медіатором комунального користування, який формує нове середовище для людини. Переломним моментом техноеволюції стає (за Маклюеном) так зване винесення нервової системи людини назовні та 3'єднання «розумних» речей у єдину соціотехнічну систему - IPP, де людина перебуває у специфічній взаємодії з середовищем техніки. В IPP відбувається коловорот інформації, матерії(руху) та енергії не тільки між людьми, а й між «розумними» речами. Такі системи функціонують без втручання людини, що призводить до все більшого набуття автономності й суверенності процесу техноеволюції. Поряд з біологічною еволюцією людини розгортається техноеволюція зі своїми законами розвитку - зовні це нагадує аутопоезис або саморух, техніка поволі відбирає у людини важелі власного поступу. Техносфера певним чином може стати «формою життя» або навіть стихією, яка вже сьогодні робить багато викликів сучасному суспільству.

Дослідження фокусується на аналізі філософської рефлексії над механізмами трансферу з ментального плану людини в простір культури артефактів «розумної» техніки, а саме IPP. Розробками понять «концепт», «концептосфера», «ноосфера», «ризома» і «ммодель» 
займалися такі мислителі: П.Абеляр, Т.Аквінський, В.Вернадський, П.Тейяр де Шарден, Ж. Дельоз і Ф.Гваттарі, М. Вартофський, С.Лихачов та ін. Коло філософських проблем взаємодії IPP з людиною, природу середовища IPP та його наслідків для людської природи наразі недостатньо досліджено, втім, дотичними питаннями займалися К.Хейлз, С.Хоружий, Д.Ріфкін, Ж.Бодріяр, М.Маклюен, Ф.Фукуяма, С. Лем, В.Савчук, М.Кастельс, Л.Уіннер, Н.Луман, П.Вермас, П.Крос.

Метою даної статті є філософське осмислення концептосфери IPP, концепту «розумна» річ» та ризоми концептів, в яку він розростається, його еволюції й кінцевого віддзеркалення та опредметнення в такому феномені техніки, як IPP.

Щоб зрозуміти процеси виникнення концептосфери IPP та іï значення для людини далі наведемо експлікацію таких понять: «медіатор», «розумна» річ», «Нтернет «розумних» речей», «орозумнення» середовища», «концепт», «концептосфера», «модель» та «трансфер».

Медіатор, медіатори (англ. media, множина від англ. medium, перекл. як «засоби комунікації») - це посередник у взаємодії людини 3 навколишнім середовищем, де, крім інформаційних медіа, представлені біологічні органи (очі, вуха, шкіра тощо) і неорганічне продовження тіла людини, наприклад, техніка (від примітивних знарядь праці й одягу до продуктів Високих технологій) $[1,84]$.

«Розумна» річ (від англ. smart thing, або смарт річ) - пристрій або програма, здатна приймати сигнал, обробляти його i/aбо створювати нові сигнали, продукти або послуги й передавати споживачу, іншій «розумній» речі або людині $[1,85]$. «Розумною» річчю важатимемо не тільки прилад, як, скажімо, смартфон або автомобіль без водія, а й програмне забезпечення, на кшталт пошукових систем (google, yandex, уаһoo) або соціальних мереж (facebook, vk.com). Останні «пропонують», а часто й «нав'язують», у списках пошуку те чи інше посилання на певний контент, «спонукають» виконати певну дію - натиснути кнопку «like», подивитися відеоролик, написати коментар, придбати товар, залишити інформацію про себе тощо.

Інтернет «розумних» речей (від англ. Internet of Things, Internet of smart Things) - це соціотехнічна система, синтез фізичного й інформаційного простору, де взаємодіють автономно люди, розумні речі, транспортна інфраструктура, бази даних, носії енергії, пошукові системи, соціальні мережі, системи штучного інтелекту тощо [1, 85]. Принциповою відмінністю IPР від Інтернету є склад користувачів - крім людей, IPР користуються «розумними» речами. 
«Орозумнення» - процес наділення людиною якостей «розумної» речі артефактам культури через техноеволюцію. «Розумні» речі дістають від людини можливість під’єднуватися до мереж самостійно. Наприклад, телефон стає «розумним» або смартфоном через під'єднання до мережі Інтернет або IPP, мультифункціональність (відеокамера, компас, накопичувач інформації, програмне забезпечення тощо) та автономність (здатність здійснювати комунікацію з іншими «розумними» речами незалежно від людини).

«Концепт» походить від латинського conceptus, що «у власному розумінні цього слова позначає зародок, зачатий у материнському лоні, але вже Макробій (V ст.) використовує його у похідному значенні, щоб сказати, що інтенції народжуються з концепту ума». Тільки в XIII ст. в працях Т.Аквінського іменник conceptus повноцінно входить у філософський дискурс, який означає сукупність правдивої інформації, «яку ангел охоплює в акті розуміння» 3 іншого боку, Т. Аквінський розуміє концепт як те, що «репрезентує в інтелігібельному порядку якусь зовнішню реальність» для людини. Семантична особливість та етимологія терміна (con-capere: «разом схопити») вказує на поєднання множини елементів у єдиному сприйнятті $[2,280]$.

Ж. Дельоз і Ф.Гваттарі вважають, що концепти існують тільки у філософії. Втім, інтуїтивне бачення концепту французькими мислителями як просторового розгортання у певні фрактали смислів, ризому або концептосферу, де нема детермінованого центру, початку і кінця, видається близьким для розуміння концепту в даному дослідженні [3, 12-14].

Більшої розробленості концепт дістав у дослідників мови. Були відібрані визначення, найбільш близькі до тих, з якими ми будемо працювати далі: К - це «відомості про те, що індивід знає, думає, уявляє про об'єкти...»; К - «своєрідні кванти знання, якими людина оперує у процесі мислення»; К - «колективне знання, заломлення через особистий досвід і емоційно оціночне переживання, об'єктивовані в матеріальних продуктах діяльності соціальних інститутів (культури, мистецтва, літератури, ЗМІ та ін.), які в процесі соціалізації опановуються, присвоюються i тим самим суб' єктивуються, стаючи реальною формою свідомості індивіда». К - «базова одиниця ментальної репрезентації»; К - «мисленнєве утворення, яке заміщає в процесі мислення велику кількість предметів одного і того самого роду»; К - «ментальне утворення, яке являє собою сховище в пам'яті людини важливих усвідомлюваних 
типізованих фрагментів досвіду» [5, 51-54].

Для подальшої експлікації поняття «концепт» та розкриття механізмів трансферу концептів з ментального плану людини в артефакти культури необхідно звернутися до розробок М. Вартофського, присвячених поняттю «модель».

Вартофський виділяє два види артефактів: «Специфічно людською формою діяльності $є$ створення і використання артефактів (включаючи знаряддя праці) у виробництві засобів існування та у відтворенні свого біологічного виду. Первинні артефакти - це артефакти, які застосовуються безпосередньо в даному виробництві. Вторинні артефакти - це артефакти, які використовуються для збереження і передачі набутих навичок або форм діяльності (практики), за допомогою яких здійснюється це виробництво. Тому вторинні артефакти - це репрезентація таких форм діяльності. У цьому розумінні вони імітують не просто об'єкти навколишнього середовища, що являють інтерес для виробництва або використовуються в ньому, а об'єкти в разі впливу на них людини, тобто вони імітують форми операцій або дій з цими об'єктами... Саме в цьому міститься зародок культурної еволюції, в ході якої адаптивні зміни у формах соціально-історичної практики змінюють собою більш повільні генетичні засоби їх збереження та передачі, які функціонують на біологічному рівні... Артефакт для еволюції культури є тим самим, чим є ген для біологічної еволюції» [4, 201, 204]. Людська пізнавальна діяльність «є засобом отримання знання про світ шляхом його перетворення з тим, щоб він задовольняв потребам, цілям, інтересам людини». Автор дослідження схиляється до посилу Вартофського щодо пізнання людини, яке не є детермінованим i змінюється 3 плином історичного процесу [4, 209-211]: природні сенсори залишаються під впливом біологічної еволюції, але ментальний план людини трансформується швидше, ніж гени. Людське око не змінило своїх властивостей за тисячі років, а неорганічне продовження ока у вигляді телескопу «Хабл», продукт розвитку ментального плану людини, дає можливість пізнавати об'єкти за межами сонячної системи. Концепт, як особливий вид репрезентації, через можливості сучасної інженерії втілився у продукт науки (в нашому випадку - у телескоп «Хабл») і «посилив» біологічні сенсори - людина в обхід еволюції почала бачити далі і більше.

В розумінні Вартофського, модель - це «...більш-менш свідома метафізична орієнтація, яка полягає не в загальнофілософських 
претензіях метафізики, а в її спробах зробити речі доступними для загального розуміння, яке необхідно науці... Це, скоріше, попереднє зобов'язання, введення в дію. Функція моделі не тільки випереджати дію, а й виконувати ії...випереджати дію значить деякою мірою вживати його» $[4,75,135]$ Моделі - це «експериментальні зонди, важлива частина техніки, створеної людством для свідомої зустрічі 3 майбутнім, але не пасивного іiї сприйняття як чогось вже сформованого... сприйняття є не тільки перцептивною діяльністю в межах існуючого світу, а й діяльністю щодо його перетворення» $[4,132]$.

Модель і концепт є репрезентаціями, вони не тотожні один одному, але близькі за значенням і стоять в одному ряду з ідеями й універсаліями.

Людина мислить концептами. Вона використовує репрезентації (концепти, метафори, моделі, ідеї тощо), в тому числі для більш продуктивної рефлексії - щоб мислити стіл, людині зручніше використати модель або концепт всієї множини столів, ніж пропускати через свідомість кожен стіл, який існує в реальності або постає у фантазії. Концепт мінімізує об'єкти у ментальному плані для зручності оперування. Концепт обов'язково включає психічний досвід (емоції, настрій, переживання, асоціації) людини, на відміну від поняття, концепт не тільки можна мислити, а й переживати. Концепт має безпосередній вплив на праксис (виробництво речей) та поезис (соціальна взаємодія) людини, він наповнює та формує ментальний план людини, а через трансфер бере участь у перетворенні матеріального світу. Концепт зберігає здобуті знання та робить їх доступними для наступних поколінь.

Під концептосферою розумітимемо певну специфічну ризомоподібну базу близьких за змістом концептів. Концепти можуть доповнювати один одного, створювати принципово відмінні концепти й концептосфери. Концепт «телефон» входить у контакт 3 концептом «розумність» («смарт»), тоді утворюється якісно відмінний артефакт - смартфон, в якому хоч і залишилася функція телефону, та вона не є ключовою.

Розглянемо зміст і генезис концептосфери «ІРР» докладніше. Концепт «Інтернет» розростається у концептосферу «Інтернет», яка включає концепти «Інтернет людей», «Інтернет речей», «Інтернет енергій», «Інтернет інформації», «Інтернет логістики», «Інтернет інфраструктури», «Інтернет комунікацій», а 3 появою «розумних» речей виникає «Інтернет «розумних речей» тощо. Останній концепт, 
у свою чергу, утворює власну концептосферу «IPР», яка включає всі вищеперелічені концепти. Але тут є принципова різниця - в усіх концептах, які належать до концептосфери «IPР», закладена ідея високого рівня автономності функціонування. «Приєднання» концепту «розумності» до всіх перелічених концептів Інтернету й подальше їх опредметнення виводить виток техноеволюції на принципово новий рівень - сучасні артефакти техніки «прагнуть» звести втручання людини у власну роботу до мінімуму.

В підсумку ми отримуємо концептосферу, або ризому концептів «ІРР», яка включає такі концепти: «Інтернет», «розумність», «розумна» річ», «Інтернет людей», «Інтернет речей», «Інтернет енергій», «Інтернет інформації», «Інтернет ринків», «Інтернет логістики», «Ннернет інфраструктури», «Інтернет комунікацій», «Інтернет послуг» тощо. Список є невичерпним, він постійно оновлюється в процесі зростання інженерного знання. Якщо концепт «Інтернет» в процесі трансферу продукує техніку й мережі, де рішення приймає людина, то концепт і концептосфера «ІРР» опредметнюється в специфічні артефакти техніки, які $з$ допомогою «розумності» перебирають до себе важелі впливу на техноеволюцію.

Трансфер - це процес перенесення репрезентацій (концептів, моделей, ідей тощо) $з$ ментального плану людини на артефакти культури. Наприклад, людина створила у власному ментальному плані концепт «штучний супутник». Цей концепт змушує шукати інженерних рішень щодо його втілення - математичні обчислення й моделювання, запуск носія супутника, встановлення зв'язку тощо. Трансфером можна вважати опредметнення концепту «штучний супутник» у таких кінцевих продуктах, як космічний літальний апарат, його обертання на геостаціонарній орбіті, отримання й передача сигналів тощо.

Як зазначалося вище, пізнання людини біологічно не детерміноване й перманентно еволюціонує. Одним із найголовніших рушіїв когнітивних здібностей людини $є$ історично зумовлений процес трансформації концептів та концептосфер. Ментальний план людини перебуває в постійному русі змін через взаємодію людини із природою, в тому числі власною. Навколишній світ стає світом-для-нас через репрезентації. Наприклад, за античних часів людина дивилася на світ концептами власної історичної епохи. Якщо це стосується транспортування вантажів, то така людина швидше за все буде взаємодіяти зі світом через концепт «гужовий транспорт»- шукатиме 
зручних наземних шляхів, майструватиме вози й розводитиме домашніх тварин, пристосованих до транспортування. Для сучасної людини найшвидшими транспортними засобами є повітряні, концепт «літак» завдає алгоритми поведінки всьому суспільству: інженери вироблятимуть та вдосконалюватимуть повітряний транспорт, а звичайна людина найвірогідніше купить квиток на літак, але не на гужовий транспорт. Втім, якщо людині треба просто побачити родичів і фізичний контакт не є обов'язковим, вона просто скористається Skype`oм.

Площини концептів та концептосфер можуть перетинатися, доповнювати або ж виключати одна одну. Наприклад, концептосфера «комунікація» включає в себе концепти «транспортний засіб», «Інтернет», «інфраструктура» тощо. Ці концепти пропонують людині зробити вибір: подолати відстань фізично або ж скористатися симуляціями, наприклад відеозв'язком. Звичайно, людина може мислити концептом наукової фантастики «телепортація», але сучасна техніка ще не дає можливості такому концепту втілитися. Щоб скористатися телепортацією, має здійснитися трансфер концепту «телепортація» у матеріальний світ.

Продукти техноеволюції XXI ст. створюють штучне середовище існування людини й перетворюють інертні технічні артефакти в активні й певною мірою самодостатні «розумні» речі. Людина візуалізує й моделює здібності власного органічного тіла, намагається посилити їх та симулювати артефактами. Інтернет «розумних» речей як культурний артефакт постійно еволюціонує через ризомоподібний розвиток концептосфери IPР. Відбуваються трансфер 3 ментального плану людини й гіпостазія «розумності» в артефактах культури: концепти «розумна» річ» та «IPР» розростаються у концептосферу або ризому, яка через процеси інженерної творчості й втілення переходить у простір культури, стає продуктом технонауки - Інтернетом «розумних» речей. Концептосфера IPP завдяки автоматизації, дигітизації й інтелектуалізації «орозумнює» середовище існування людини - така дійсність перестає бути пасивною, відбуваються поглиблення та пришвидшення обміну інформації, енергії та руху в соціотехнічних системах, між людиною та людиною, між людиною та техносферою, між людиною та природою тощо.

Концептосфера «ІРР» нагадує окуляри, які сучасна людина використовує в XXI ст. Кожен об'єкт, що потрапляє в поле діяльності такої людини, повинен «орозумнюватися». Концептосфера «IPР»- 
одна 3 призм, крізь яку інженер дивиться на світ. Артефакти культури, на які падає промінь уваги сучасного інженера, обернуться або вже обертаються на «розумні» речі. Соціотехнічна система IPP захоплює нові топоси діяльності людини, розростається і розгалужується, перетворюючи культуру, побут, мову, повсякденну комунікацію, науку, мистецтво, освіту, медицину тощо. Концептосфера «ІРР» змушує мислити навколишній світ властивими їй категоріями, вона нав'язує людині метафору «розумності», через яку людина комунікує з суспільством, природою, сама з собою. Техносфера IPP задає алгоритми дії, найпростіший - це вимушеність користувача під'єднувати прилади до мереж IPР, наприклад, побутову техніку, планшет, автомобіль. Якщо ж людина ігноруватиме такі поєднання, тоді виникне ризик втратити зв'язок із суспільством: відсутність власного профілю в соціальних мережах, ігнорування прогнозів заторів з допомогою сервісів Google maps (в тому числі для власного автомобіля без водія), відмова від використання «розумної» побутової техніки зроблять неможливим соціально адекватну практику побуту такої людини. В епоху IPP вихід із такої соціотехнічної системи буде тотожним втечі людини ХХ ст. до лісу або печери.

Філософська рефлексія над проблематикою концептосфери «IPP» має важливе значення для адекватного розуміння процесів еволюції сучасної людини. Когнітивно перетворювальна практика змінюється протягом історичного процесу. Пізнання не є пасивним спогляданням, ментальний план перебуває у постійній взаємодії зі світом і бере участь у перетворенні останнього. Найбільшого впливу людина зазнає в кінцевій фазі трансферу концептів, через контакт 3 артефактами техніки. Концептосфера «ІРP», як і будь-яка інша, змушує людину діяти в певній парадигмі. Світ, створений феноменом техніки IPP, стає носієм таких гіпостазованих характеристик людини, як «розумність» та «форма життя» (за Уіннером). Техніка «ІРР» характеризується аутопоезисом, вона здатна збирати, обробляти дані, на основі яких редагує власні алгоритми дій. Такі продукти інженерної думки стали ще одним кроком в симуляції когнітивного фунціоналу людини технікою. Зовнішнє неорганічне продовження органічного тіла людини, а саме середовище IPP, в якій представлені симуляція, кіберпростір та їхнє фізичне втілення, оновлює проблематику топосу і меж людського тіла. 


\section{ЛІТЕРАТУРА}

1. Омельченко Ю.О. Проблема перетворення людської природи в епоху Інтернету «розумних» речей // Мультиверсум. Філософський альманах. №10 (138). - 2014. - С. 79-90.

2. Паначчіо K. Conceptus // Європейський словник філософій: Лексикон неперекладностей. Пер. $з$ фр. - Том перший. - К., 2011. - С.279-283.

3. Делез Ж., Гваттари $\Phi$. Тысяча плато. Капитализм и шизофрения. - М., 2010. - $895 \mathrm{c}$.

4. Вартофський М. Модели. Репрезентация и научное понимание. - М., 1988. - 508 c.

5. Приходько А.Н. Концепты и концептосистемы. - Днепропетровск, 2013.-307 с.

Омельченко Ю.О. Концептосфера «Інтернет «розумних» речей» та іï філософський смисл.

В статті досліджуються механізми виникнення концептосфери Iнтернету «розумних» речей. Представлено розуміння процесів трансферу 3 ментального плану людини у простір культури концептів. Дослідження вказує на важливість еволюції ментального плану людини для процесів трансформації когнітивно перетворювальної практики людини. Такий феномен техніки, як IPP, сформував нове ментальне середовище - концептосферу «IРР», яка має важливе значення для формування ментального плану людини. Концептосфера «ІРР» має вплив у всіх сферах діяльності людини: науці, техніці, культурі, медицині, економіці, побуті тощо. Концептосфера «IPP», як і сама техносфера IPP, характеризується аутопоезисом та автономністю.

Ключові слова: концепт, концептосфера, Інтернет «розумних» речей, трансфер.

Омельченко Ю.О. Концептосфера «Интернет «умных» вещей» и ее философский смысл.

В статье исследуются механизмы возникновения концептосферы «Интернет «умных» вещей». Представлено понимание процессов трансфера с ментального плана человека в пространство культуры концептов. Исследование указывает на важность эволюции ментального плана человека для процессов трансформации когнитивно преобразовательной практики человека. Такой феномен техники, как ИРР, создает новую ментальную среду - концептосферу «ИРР», которая имеет важное значение для формирования ментального плана человека. Концептосфера «ИРР» имеет влияние во всех сферах деятельности человека: в науке, технике, культуре, медицине, экономике, быту и т.д. Концептосфера «ИРР», как и сама техносфера ИРР, характеризуется аутопоэзисом и автономностью. 
Ключевые слова: концепт, концептосфера, Интернет «умных» вещей, трансфер.

Omelchenko Y.O. Conceptosphere «Interne o of smart things» and its philosophical meaning.

The article investigates the mechanisms of appearance of Conceptosphere «Interne o of smart things». Presented the understanding of processes of concepts' transfer from the mental plane of human in the cultural space. The study points to the importance of mental plan evolution for transformation human cognitive transformative practice. Such phenomenon of technology as IoT, formed a new mental environment - conceptosphere «IoT», which is essential for the formation of human mental plane. Conceptosphere «IoT» has influence in all spheres of human activity: science, technology, culture, medicine, economics, life and more. Conceptosphere «Iot» along with the technosphere IoT is characterized with autopoiesis and autonomy.

Key words: concept, conceptosphere Internet of smart things, transfer. 